\title{
HYDROGEOCHEMICAL ASSESSMENT OF GROUNDWATER IN KALTUNGO AND ENVIRONS, NORTHEASTERN NIGERIA.
}

J.M. ISHAKU AND A. ABDULHAKEEM

(Received 31 July 2009; Revision Accepted 10, April 2010)

\begin{abstract}
Analytical results indicate that groundwater samples from kaltungo and environs are polluted due to high concentrations of iron, fluoride, nitrate, and coliform bacteria. Iron concentrations range from $1.9 \mathrm{mg} / \mathrm{l}$ to $4.8 \mathrm{mg} / \mathrm{l}$, fluoride values range from $0.6 \mathrm{mg} / \mathrm{l}$ to $1.9 \mathrm{mg} / \mathrm{l}$, and nitrate concentrations range from $46.8 \mathrm{mg} / \mathrm{l}$ to $164 \mathrm{mg} / \mathrm{l}$ while coliform number counts range from nil to 80 number counts. The results further reveal that the water is generally good for agricultural uses. The SAR values range from $0.003 \mathrm{meq} / \mathrm{l}$ to $0.38 \mathrm{meq} / \mathrm{l}, \mathrm{RSC}$ values range from $-6.20 \mathrm{meq} / \mathrm{l}$ to $4.97 \mathrm{meq} / \mathrm{l}$, EC values vary from $160 \mu \mathrm{S} / \mathrm{cm}$ to $790 \mu \mathrm{S} / \mathrm{cm}$, and TDS ranges from $80 \mathrm{mg} / \mathrm{l}$ to $400.5 \mathrm{mg} / \mathrm{l}$. However, the water may not be suitable for some industries due to high concentrations of iron, bicarbonate, and total hardness. Bicarbonate values range from $206 \mathrm{mg} / \mathrm{l}$ to $612 \mathrm{mg} / \mathrm{l}$, and total hardness range from $73.4 \mathrm{mg} / \mathrm{l}$ to $163.7 \mathrm{mg} / \mathrm{l}$. Piper trilinear plots classified the water into $\mathrm{Ca}-(\mathrm{Mg})-\mathrm{HCO}_{3}$ which belongs to the normal alkaline fresh water type. Based on $\mathrm{Mg}^{2+} / \mathrm{Ca}^{2+}$ ratio, about $39 \%$ of water samples reveal water from silicate aquifer. Plots of logTDS against $\mathrm{Na}^{+} /\left(\mathrm{Na}^{+}+\right.$ $\mathrm{Ca}^{2+}$ ) reveal that the groundwater chemistry is influenced by evaporation, weathering induced dissolution, and dilution effects. The water would require treatment for human consumption and for industrial applications. It is recommended that regular groundwater quality monitoring will ensure groundwater quality protection and conservation.
\end{abstract}

KEY WORDS: Groundwater chemistry, silicate aquifer, alkaline fresh water, kaltungo area, polluted.

\section{INTRODUCTION}

Groundwater is considered the healthiest source of drinking water, but when contaminated, may lead to health problems (Aloa and Ige, 2003). The source of groundwater contamination could be natural through groundwater-rock interaction or through anthropogenic which involve human activities that can affect groundwater quality. Groundwater pollution which is man- made is worst than natural pollution as it eventually renders water less suitable for use than its original state (Abimbola et al., 2005). The study area is located between latitudes $9^{0} 48^{\prime} 00 \mathrm{~N}$ to $9^{0} 50^{\prime} 38 \mathrm{~N}$ and longitudes $11^{\circ} 16^{\prime} \mathrm{OOE}$ to $11^{0} 19^{\prime} 45^{\prime \prime} \mathrm{E}$ (Fig.1). It is accessible through the Bauchi-Gombe-Kaltungo and Numan-Cham-Kaltungo Federal Highway. The study area forms part of the Gongola arm of the Benue Trough. The area has a mean maximum temperature of $31^{\circ} \mathrm{C}$ and average annual rainfall of $1550.7 \mathrm{~mm}$. The area is characterized by moderate to high relief which stands out within the general elevation, among which is the famous Tangale peak (Carter et al., 1963). The topography of the area rises from 402 metres to 702 metres above mean sea level. The area is drained by the River Kaltungo which flows from the north east towards the southwest.

The population of the area is about 183,000 (NPC, 2006), and the people are predominantly farmers, and they also rear cattle. The major sources of water supply in the area are surface waters including Rivers, streams ponds and groundwater which is obtained from hand-dug wells and boreholes. Most residents in the area use pit latrines and waste disposal is indiscriminately carried out. These practices could be responsible for the degradation of groundwater quality, and thus unsuitable for human consumption.

This study evaluates the influence of anthropogenic activities and geology on the groundwater quality of the study area and the peculiar use of the water for agricultural, industrial and domestic purposes.

\section{GEOLOGY AND HYDROGEOLOGY OF THE AREA}

The study area is located in the Upper Benue trough which has been variously described as intracontinental rift basin ( Benkhelil, 1982; Ofoegbu, 1988 and Okereke, 1988). According to

J.M. Ishaku Department of Geology,Federal University of Technology, Yola, Nigeria.

A. Abdulhakeem Department of Geology,Federal University of Technology, Yola, Nigeria. 


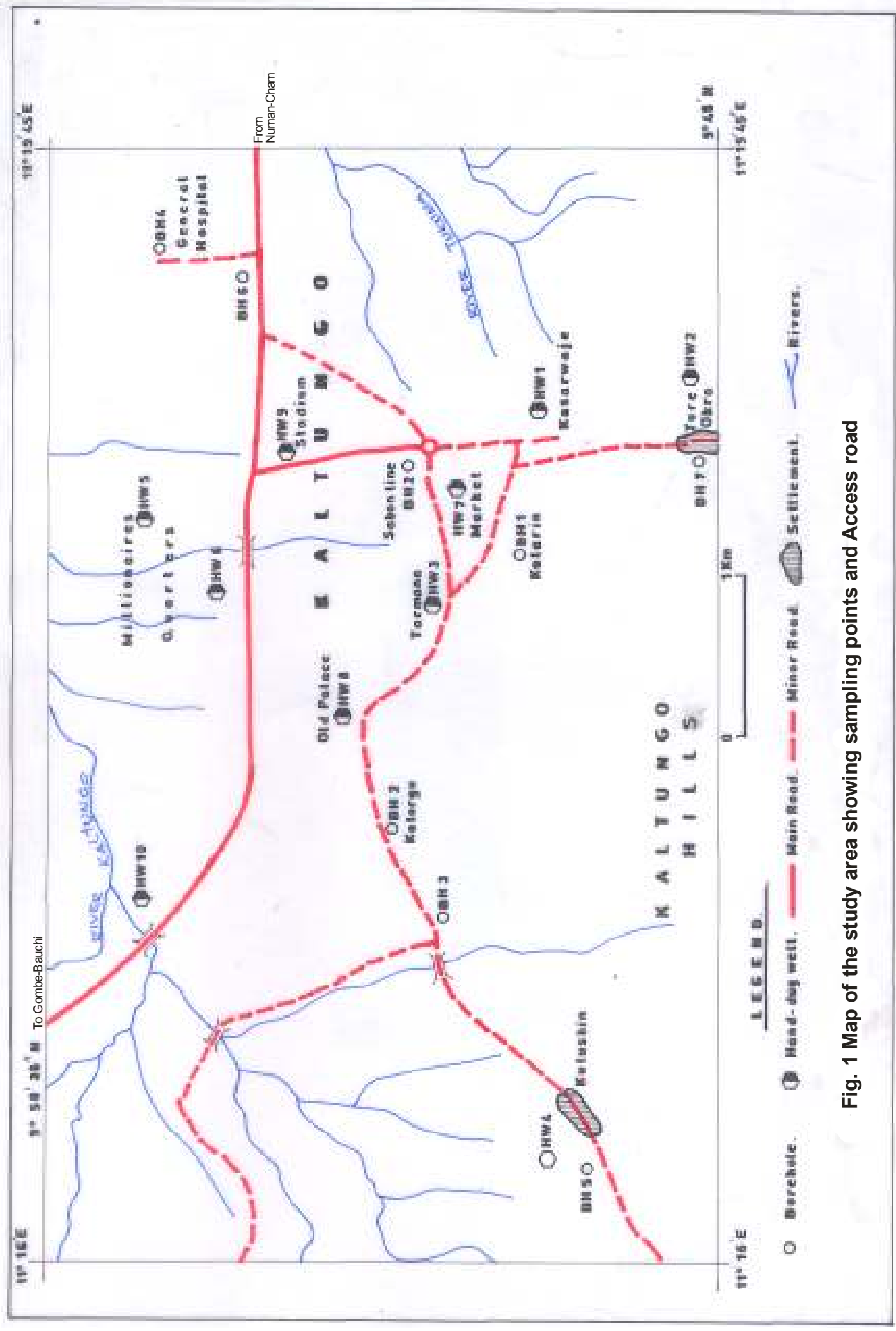


Ntekim and Orazulike (2004) that the present tectonic setting of the area is influenced by the late Cretaceous intense compressional earth movements dominated by series of long and narrow simple fold structures. They went further to state that large scale faulting occurred after the faulting events and resulted in grabens. The reactivation of the major basement faults is responsible for the sinistral faults in Kaltungo, TeliWuyo and Gombe areas. Bassey (2000 and 2005) identified the Chibok lineaments which align $\mathrm{N} 50^{\circ} \mathrm{E}$ to be similar to the trend of the Kaltungo fault zone and the Wuyo-Gubrunde lineaments. Bassey (2006) also reported a Chibok NE-SW trending lineaments which are intrabasement extension of the Benue trough lineaments traceable to Kaltungo inlier through WuyoGubrunde-Shani fault zones. The area is underlain by the basement complex rocks which include porphyritic and biotite granite (Fig.2). The porphyritic granite underlies most parts of the study area while the biotite granite underlies the southern portion of the study area. The biotite granite underlies a small portion of the northern part of the study area. The porphyritic and biotite granites belong to the older granite of the Nigerian basement complex. The porphyritic granites are coarse to very coarse grained with large white or pink prismatic phenocrysts of microcline while the biotite granite have granular texture with wide range of grain sizes (Rahman, 1976, Van Breeman, et al., 1977). Groundwater occurs in the weathered portion of the basement rock as well as fractures in the basement rocks.

Borehole lithologic sections (Fig.3) revealed fracture aquifer which range from $12 \mathrm{~m}$ to $24 \mathrm{~m}$. Boreholes in the area generally have average depth of $30 \mathrm{~m}$ while hand-dug wells have depths ranging from $3 \mathrm{~m}$ to $6 \mathrm{~m}$. The fracture aquifer yields range from $3.3 \mathrm{l} / \mathrm{s}$ to $16.71 / \mathrm{s}$ (Gombe State Rural Water Supply, 2003).

\section{METHODOLOGY}

This study involves the collection of Eighteen (18) water samples from the different water sources in February, 2007) (Fig.1). Eight (8) water samples were collected from boreholes while Ten (10) water samples were collected from hand-dug wells. The water samples were collected in one-litre containers which were rinsed with the samples to be collected according to Barcelona et al (1985) method. Water samples were collected from the discharge of existi 


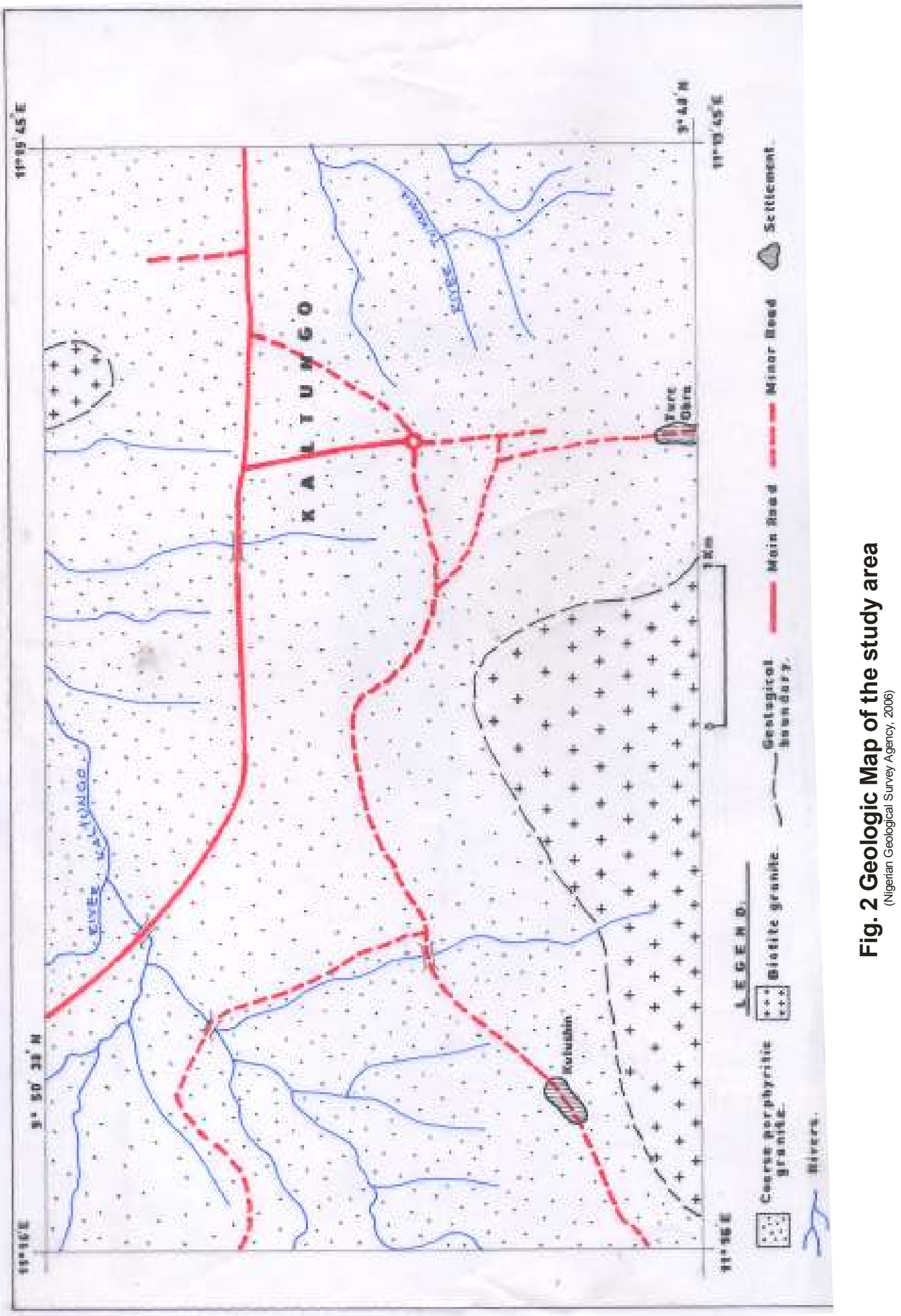



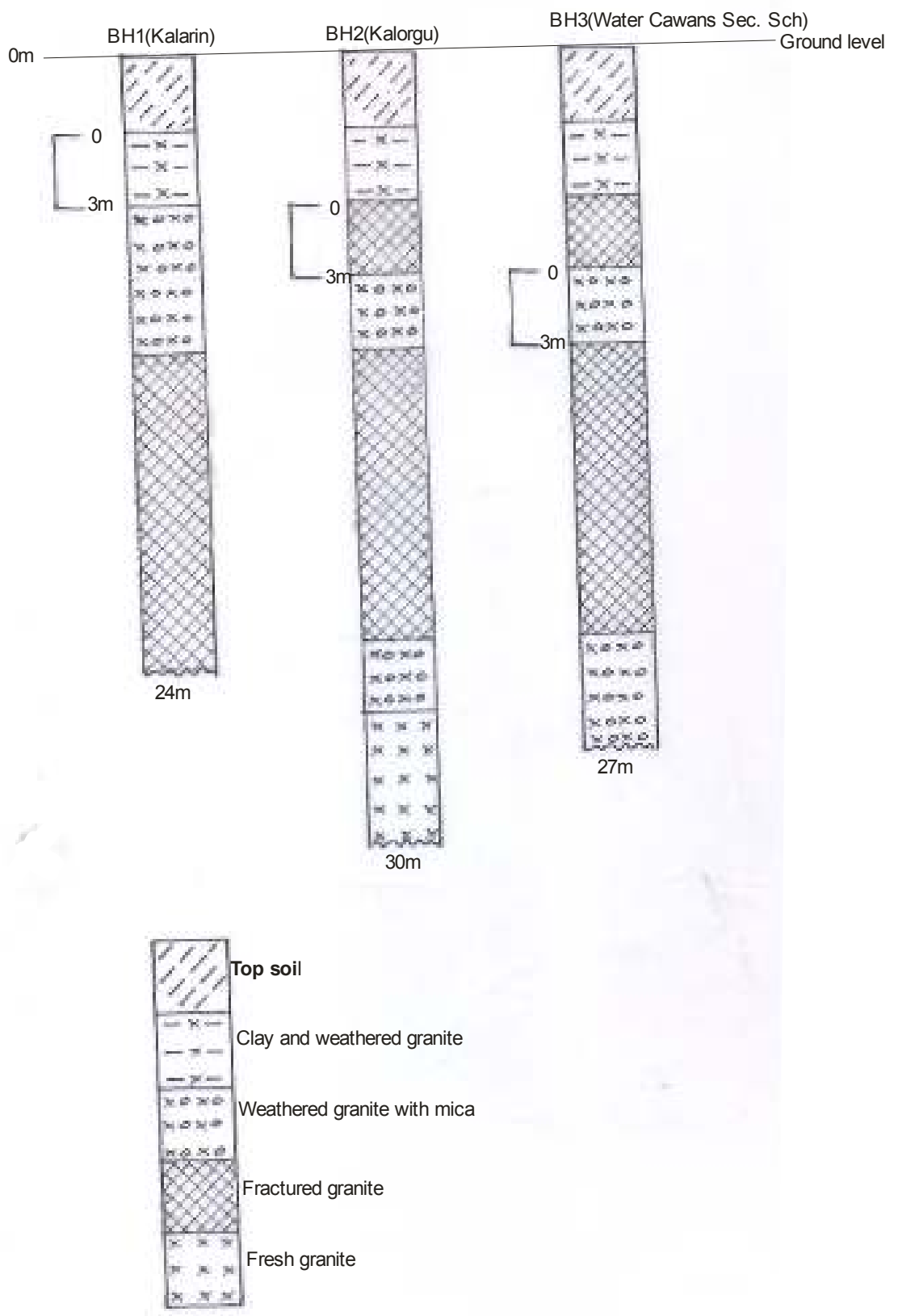

Fig. 3 Lithologic sections of some boreholes in the study area 
hand-dug wells and boreholes according to Chilton (1992) method. Field parameters such as Temperature, $\mathrm{pH}$, Conductivity (EC), and Total Dissolved Solids (TDS) were measured in the field using TDS/Conductivity meter (HACH KIT) (Model 44600-00) while pH was measured using HANNA pH meter (Model HI 28129).

The samples were analyzed chemically using $\mathrm{HACH}$ Spectrophotometer (Model DR/2000, USA) and titrimetric method using digital titrator $(\mathrm{HACH})$ (Model 16-19-01). The samples for bacteriological analysis were carried out within 24 hours using the membrane filtration method employing the use of membrane assemblage (Vacuum pump, Asbestos pad, Bukner flask and membrane funnel) and Leica Quebec Dark field colony counter. The bacteriological analysis was carried out according to WHO (1985).

\section{RESULTS AND DISCUSSION Results}

The results of the physical, chemical and bacteriological characteristics of the water are presented in Table1.

\section{Water quality for domestic uses}

Table 1 revealed that $\mathrm{pH}$ of the borehole water samples range from 7.4 to 8.1 , and values range from 6.9 to 8.2 in the hand-dug wells. The electrical conductivity values of the samples from boreholes range from $204 \mu \mathrm{S} / \mathrm{cm}$ to $650 \mu \mathrm{S} / \mathrm{cm}$, values from the hand-dug wells vary from $160 \mu \mathrm{S} / \mathrm{cm}$ to $790 \mu \mathrm{S} / \mathrm{cm}$. The values of the chemical parameters revealed that the total dissolved solids (TDS) from the boreholes range from $122 \mathrm{mg} / \mathrm{l}$ to $346 \mathrm{mg} / \mathrm{l}$, and from $80 \mathrm{mg} / \mathrm{l}$ to $400 \mathrm{mg} / \mathrm{l}$ in the hand-dug wells. The values of the total hardness range from $73.4 \mathrm{mg} / \mathrm{l}$ to $103.4 \mathrm{mg} / \mathrm{l}$ in the borehole samples, and from $70.8 \mathrm{mg} / \mathrm{l}$ to $162.9 \mathrm{mg} / \mathrm{l}$ in the hand-dug well samples. The values of the major cations revealed that calcium concentrations from boreholes range from $37.5 \mathrm{mg} / \mathrm{l}$ to $70.2 \mathrm{mg} / \mathrm{l}$, and $20.6 \mathrm{mg} / \mathrm{l}$ to $111.7 \mathrm{mg} / \mathrm{l}$ in the hand-dug wells. Potassium values range from $2.2 \mathrm{mg} / \mathrm{l}$ to $8.6 \mathrm{mg} / \mathrm{l}$ in boreholes, and $3 \mathrm{mg} / \mathrm{l}$ to $8.1 \mathrm{mg} / \mathrm{l}$ in the handdug wells. Sodium values range from $0.1 \mathrm{mg} / \mathrm{l}$ to $6.4 \mathrm{mg} / \mathrm{l}$ in boreholes, and $0.3 \mathrm{mg} / \mathrm{l}$ to $7.2 \mathrm{mg} / \mathrm{l}$ in the hand-dug wells. Magnesium concentrations range from $22.8 \mathrm{mg} / \mathrm{l}$ to $51.3 \mathrm{mg} / \mathrm{l}$ in the borehole samples, and values vary from $35.9 \mathrm{mg} / \mathrm{l}$ to $88.5 \mathrm{mg} / \mathrm{l}$ in the hand-dug wells. The values of the 


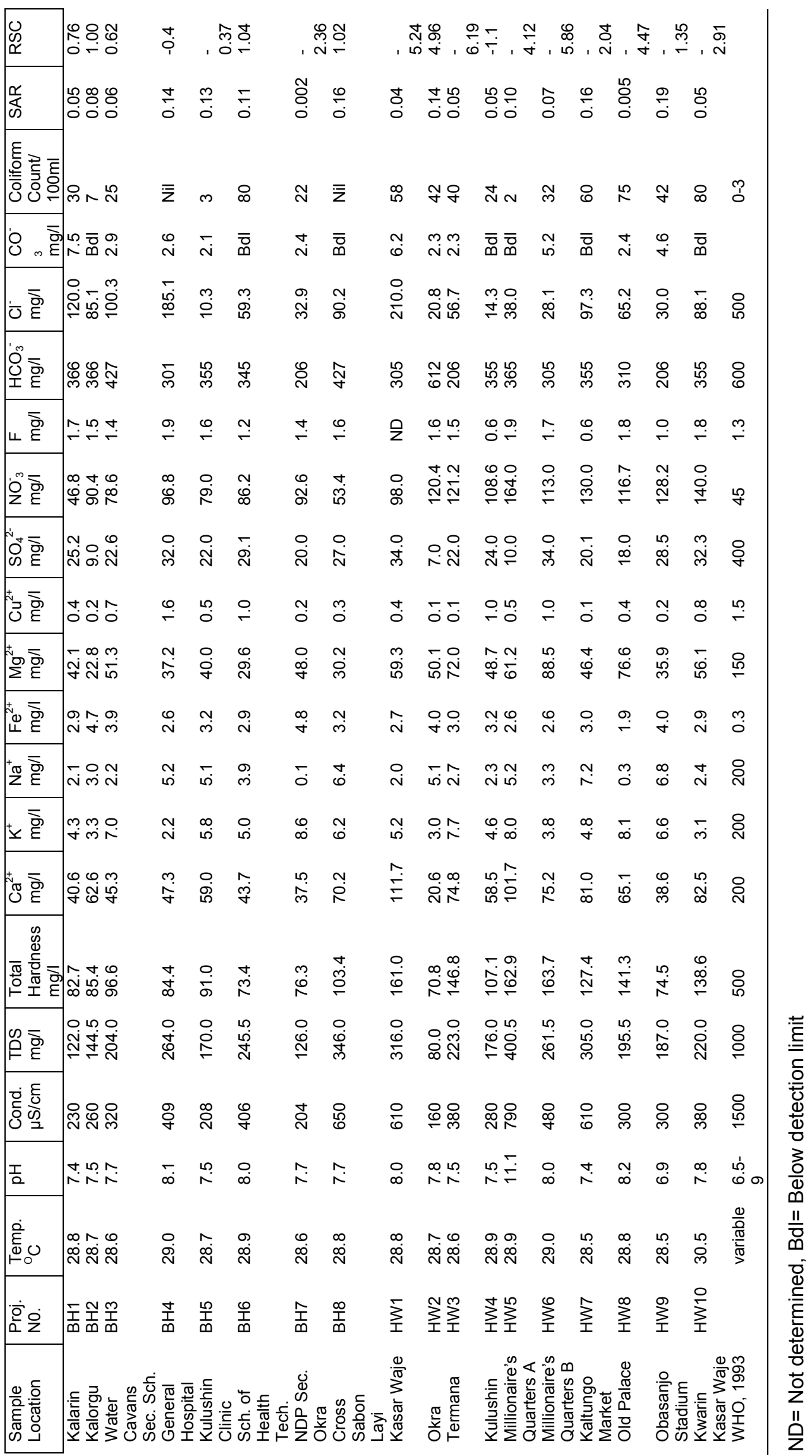


major anions revealed that sulphate values from the borehole samples vary from $9 \mathrm{mg} / \mathrm{l}$ to $32 \mathrm{mg} / \mathrm{l}$, and from $7 \mathrm{mg} / \mathrm{l}$ to $34 \mathrm{mg} / \mathrm{l}$ in the hand-dug wells. Bicarbonate values range from $206 \mathrm{mg} / \mathrm{l}$ to $427 \mathrm{mg} / \mathrm{l}$ in boreholes, and $206 \mathrm{mg} / \mathrm{l}$ to $612 \mathrm{mg} / \mathrm{l}$ in the hand-dug wells. Chloride concentrations vary from $10.3 \mathrm{mg} / \mathrm{l}$ to $186.1 \mathrm{mg} / \mathrm{l}$ in boreholes, and values range from $14.3 \mathrm{mg} / \mathrm{l}$ to $210 \mathrm{mg} / \mathrm{l}$ in the hand-dug wells. The values of carbonate range from $0 \mathrm{mg} / \mathrm{l}$ to $7.5 \mathrm{mg} / \mathrm{l}$ in boreholes, and from $0 \mathrm{mg} / \mathrm{l}$ to $6.2 \mathrm{mg} / \mathrm{l}$ in the hand-dug wells. Values of iron concentrations vary from $2.6 \mathrm{mg} / \mathrm{l}$ to $4.8 \mathrm{mg} / \mathrm{l}$ in boreholes, and $1.9 \mathrm{mg} / \mathrm{l}$ to $4 \mathrm{mg} / \mathrm{l}$ in the hand-dug wells. The values of copper in boreholes range from $0.2 \mathrm{mg} / \mathrm{l}$ to $1.6 \mathrm{mg} / \mathrm{l}$, and $0.1 \mathrm{mg} / \mathrm{l}$ to $1.0 \mathrm{mg} / \mathrm{l}$ in the hand-dug wells. The values of Flouride range from $1.2 \mathrm{mg} / \mathrm{l}$ to $1.9 \mathrm{mg} / \mathrm{l}$ in boreholes, and values vary from $0.6 \mathrm{mg} / \mathrm{l}$ to $1.9 \mathrm{mg} / \mathrm{l}$ in hand-dug wells. The colliform bacteria from the borehole samples range from nil to 80 number counts per $100 \mathrm{mls}$, and from 2 to 80 number counts in the hand-dug wells. Nitrate concentrations vary from $46.8 \mathrm{mg} / \mathrm{l}$ to $96.8 \mathrm{mg} / \mathrm{l}$ in borehole samples, and $98 \mathrm{mg} / \mathrm{l}$ to $164 \mathrm{mg} / \mathrm{l}$ in the handdug wells.

\section{Water quality for Agriculture}

The criteria adopted for the evaluation of water quality for agricultural practices include SAR, RSC and Salinity hazard. From Table1, the Sodium Adsorption Ratio (SAR) values range from $0.003 \mathrm{meq} / \mathrm{l}$ to $0.38 \mathrm{meq} / \mathrm{l}$, and Residual Sodium Carbonate (RSC) values range from $-6.20 \mathrm{meq} / \mathrm{l}$ to $4.97 \mathrm{meq} / \mathrm{l}$. The Salinity hazard is expressed as Elecrical conductivity (EC) and total dissolves solids (TDS). The EC values range from $160 \mathrm{mg} / \mathrm{l}$ to $790 \mathrm{mg} / \mathrm{l}$, and TDS vary from $80 \mathrm{mg} / \mathrm{l}$ to 400.5mg/l.

\section{Water quality for industrial activities}

The criteria for the evaluation of water quality for industrial applications revealed that iron concentrations range from $1.9 \mathrm{mg} / \mathrm{l}$ to $4.8 \mathrm{mg} / \mathrm{l}$, sodium range from $0.1 \mathrm{mg} / \mathrm{l}$ to $7.2 \mathrm{mg} / \mathrm{l}$, sulphate values vary from $7 \mathrm{mg} / \mathrm{l}$ to $34 \mathrm{mg} / \mathrm{l}$. The concentrations of bicarbonate range from $206 \mathrm{mg} / \mathrm{l}$ to $612 \mathrm{mg} / \mathrm{l}$, Chlorides range from $10.3 \mathrm{mg} / \mathrm{l}$ to $210 \mathrm{mg} / \mathrm{l}$ while total hardness, fluoride, and $\mathrm{pH}$ values range from $70.8 \mathrm{mg} / \mathrm{l}$ to $163.7 \mathrm{mg} / \mathrm{l}, 0.6 \mathrm{mg} / \mathrm{l}$ to $1.9 \mathrm{mg} / \mathrm{l}$, and 6.9 to 8.2 respectively.

\section{Discussion}

The physical, chemical and bacteriological parameters for the evaluation of water quality revealed that all the $\mathrm{P}^{\mathrm{H}}$ values from the different water sources are below the maximum limit of World Health Organization (WHO). The electrical conductivity (EC) values are also below the WHO recommended limits. All the values of the total dissolved solids (TDS) are also below the $\mathrm{WHO}$ maximum permissible limits. The values of total hardness are also below the recommended limits. All the values of the major cations and anions also fall below the WHO maximum permissible limits. However one sample (Hw 2) revealed high concentration of bicarbonate value of $612 \mathrm{mg} / \mathrm{l}$ which is above the maximum permissible limit of $600 \mathrm{mg} / \mathrm{l}$. The values of copper from the different water sources are below the recommended limit of $\mathrm{WHO}$, one sample $(\mathrm{BH} 4)$ however recorded a value of $1.6 \mathrm{mg} / \mathrm{l}$ which is above the recommended limit. Iron concentrations are all above the recommended limit. Iron concentration values are all above the recommended limit of WHO of $0.3 \mathrm{mg} / \mathrm{l}$. High iron concentration has taste problem and can precipitates and stains if in excess. Fluoride values range from $0.6 \mathrm{mg} / \mathrm{l}$ to $1.9 \mathrm{mg} / \mathrm{l}$, most samples revealed concentrations above the recommended limit of $1 \mathrm{mg} / \mathrm{l}$. A concentration value of $0.6 \mathrm{mg} / \mathrm{l}$ is regarded as the permissible limit, and $1.3 \mathrm{mg} / \mathrm{l}$ is the permissible limit maximum in drinking water in many countries (WHO, 1984). Beyond 1.5ppm excessive fluoride in drinking water has been reported to cause mottling teeth. Concentrations above $4 \mathrm{ppm}$ may affect teeth structure (Hem, 1959). Fluoride at concentration levels of 3-6ppm can cause skeletal flourosis (WHO, 1984). Based on the above various effects of fluoride concentrations in drinking water, the people in the area are likely to suffer from mottling of teeth. High fluoride concentrations in drinking water in the area could be from the mineralogical dissolutions of fluorite minerals associated with the rock types in the area. The values of total hardness are all below the recommended limit of $500 \mathrm{mg} / \mathrm{l}$. According to Mc Carty, 1967, hardness values between $0-75 \mathrm{mg} / \mathrm{l}$ is classified as soft water, $75-150 \mathrm{mg} / \mathrm{l}$ as moderately hard, $150-300 \mathrm{mg} / \mathrm{l}$ as hard and greater than $300 \mathrm{mg} / \mathrm{l}$ as very hard. The water in the area therefore ranges from soft to hard water. Nitrate concentration values revealed high concentrations above the recommended limit of $45 \mathrm{mg} / \mathrm{l}$ of WHO. High nitrate concentration is known to cause an increase in risk of babies developing infant methaemoglobinaemia, a disease commonly known as 'blue baby' syndrome (Canter, 1996; Jana and Kent, 2009). Other health hazards due to high nitrate concentrations include hypertension, congenital malformations and spontaneous abortions (Spalding and Exner, 1993). Bowman (1994) stated that increased concentration of nitrate often cause blood disorders. Nitrate pollution in the area could be due to shallow nature of hand-dug wells and boreholes, indiscriminate waste disposal practices, use of manure and chemical fertilizers on farm lands. Nitrate is produced from nitrogen following the equation describing the process below

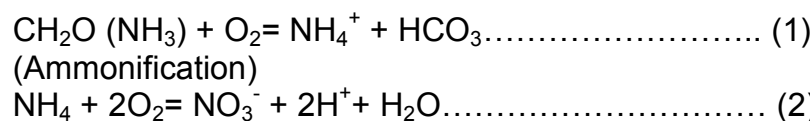

\section{HYDROGEOCHEMICAL ASSESSMENT OF GROUNDWATER IN KA}

The coliform number counts range from nil to 80 coliform number counts revealed that most samples exceeded the recommended limit of $\mathrm{WHO}$ of 3 number counts with the exception of $\mathrm{BH} 4, \mathrm{BH} 5, \mathrm{BH} 8$, and $\mathrm{Hw} 5$ are within the recommended limit. High coliform number counts in the area could be from indiscriminate waste disposal practices, and sewage effluent following the use of pit latrines by most residents. The SAR values range from 0.003 to $0.38 \mathrm{meq} / \mathrm{l}$, indicating that the water can be used on all classes of soils (Table 2). The RSC values which vary from -6.20 to $4.97 \mathrm{meq} / \mathrm{l}$, revealed that about $67 \%$ of the samples fall within the most desirable class (Table 2). EC values range from $160 \mu \mathrm{S} / \mathrm{cm}$ to 790 $\mu \mathrm{S} / \mathrm{cm}$, all values revealed that the water in the area has no salinity problem, except sample Hw5 revealed a 
value of $790 \mu \mathrm{S} / \mathrm{cm}$ which is higher than the critical value (Table 2). Parameters used in the evaluation of water quality for industrial applications revealed that all the concentration values of iron exceeded $0.2 \mathrm{mg} / \mathrm{l}$, and therefore the water in the area may not be suitable for some industries (Table 3). According to Todd, 1980, more than $65 \mathrm{mg} / \mathrm{l}$ of sodium is known to cause problems in ice manufacture. Consequently, the values of sodium from the water sources are below the above standard limit. The water in the study area is good for industrial use as far as sodium is concern. Also, the values of sulphate suggest water of good quality, and can be used for industrial 


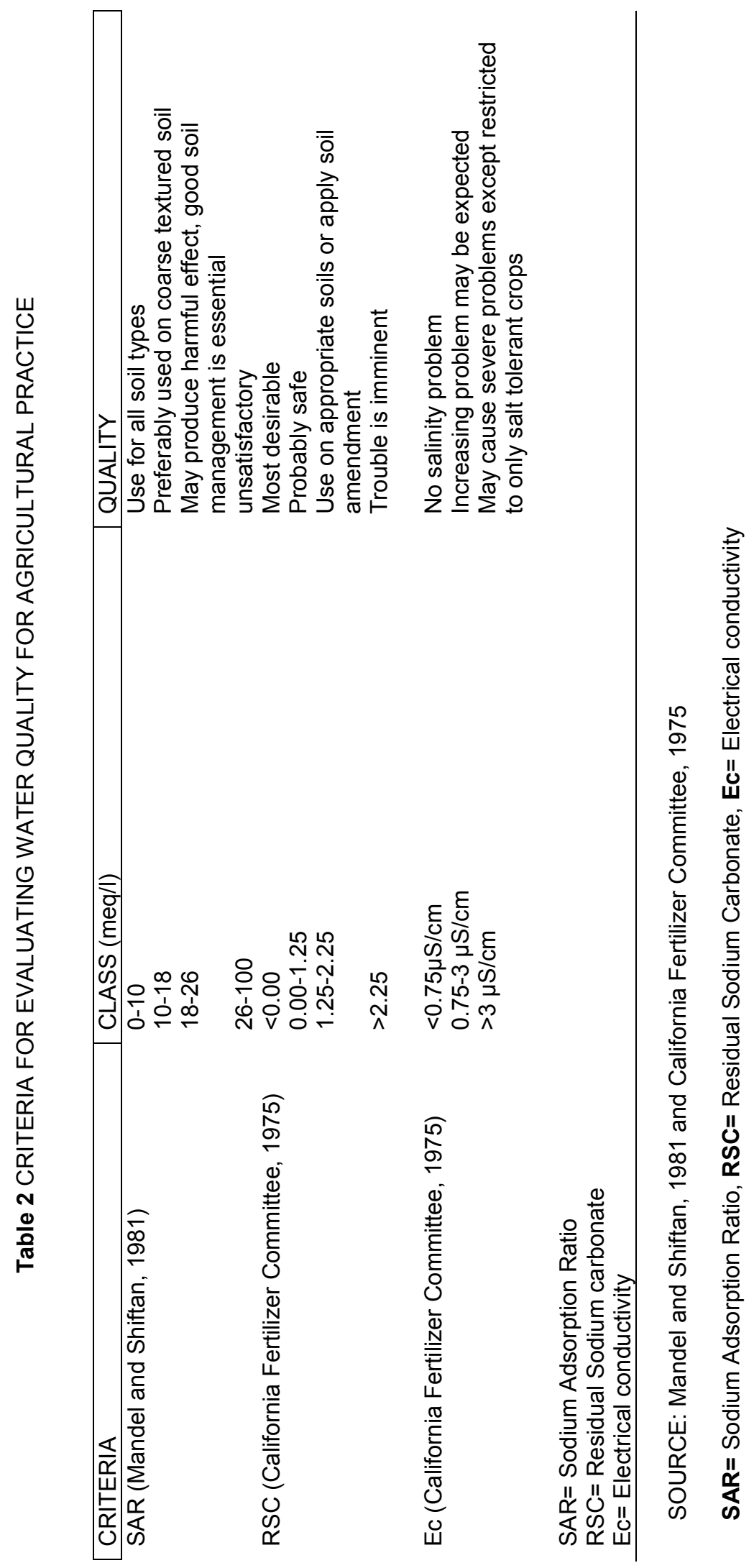


Table 3 PARAMETERS USED IN THE EVALUATION OF WATER FOR INDUSRIAL USE

\begin{tabular}{|c|c|c|}
\hline PARAMETERS & $\begin{array}{l}\text { CONCENTRATION } \\
\text { LIMITS }\end{array}$ & QUALITY \\
\hline Iron & $>0.2 \mathrm{mg} / \mathrm{l}$ & Objectionable for most industries \\
\hline Sodium & $>65 \mathrm{mg} / 1$ & Can cause problem in ice manufacture \\
\hline Sulphate & $>250 \mathrm{mg} / \mathrm{l}$ & Not suitable for carbonated beverages \\
\hline Bicarbonate & $30-250 \mathrm{mg} / 1$ & $\begin{array}{l}\text { Suitable for brewing, carbonated beverages, food } \\
\text { canning and freezing, food processing }\end{array}$ \\
\hline \multirow[t]{2}{*}{ Chloride } & $<100 \mathrm{mg} / 1$ & $\begin{array}{l}\text { Suitable for textile processing, paper manufacture, } \\
\text { and synthetic rubber manufacture }\end{array}$ \\
\hline & $<250 \mathrm{mg} / \mathrm{l}$ & Suitable for food processing \\
\hline $\begin{array}{l}\text { Total dissolved } \\
\text { solids }\end{array}$ & $<300 \mathrm{mg} / 1$ & $\begin{array}{l}\text { Suitable for dyeing and manufacture of plastics, pulp } \\
\text { paper, rayon }\end{array}$ \\
\hline Fluoride & $0.2-2.4 \mathrm{mg} / 1$ & $\begin{array}{l}\text { Suitable for brewing, carbonated beverages, food } \\
\text { canning and freezing, food equipment washing, and } \\
\text { food processing }\end{array}$ \\
\hline $\mathrm{pH}$ & $6-8.3$ & $\begin{array}{l}\text { Suitable for brewing, confectionery, food canning } \\
\text { and freezing, Rayon manufacture, and taining }\end{array}$ \\
\hline \multirow[t]{4}{*}{ Hardness } & $0-50 \mathrm{mg} / 1$ & Suitable for textile \\
\hline & $10-250 \mathrm{mg} / 1$ & Food processing \\
\hline & $50-500 \mathrm{mg} / 1$ & Taining \\
\hline & $200-250 \mathrm{mg} / \mathrm{l}$ & Carbonated beverages \\
\hline
\end{tabular}

(Source: Todd, 1980)

activities. Bicarbonate values revealed that the water quality may not be suitable for some industries (Table 3 ) as most of the values (83\%) exceeded the recommended limit. The values of chloride revealed that the water quality is suitable for some industries as $78 \%$ of the values are within the recommended limit of good quality water for industrial use. The values of total dissolved solids, fluorides, and $\mathrm{pH}$ also revealed water of good quality for industrial use. The concentration values of total hardness revealed that the water may not be suitable for the textile industries, but may be suitable for taining, carbonated beverages and food processing.

\section{CHARACTERIZATION OF THE GROUNDWATER}

Plots of chemical data on piper Trilinear (1944) (Fig. 4) revealed that the water can be classified into $\mathrm{Ca}-$ (Mg) $-\mathrm{HCO}_{3}{ }^{-}$which belongs to the normal alkaline fresh water type. According to Amadi (1987) that this water type is typical of the Nigerian basement complex terrain with limited mixing perhaps reflecting a primary stage of evolution of its ground water system. The bicarbonate could have resulted from the reaction of carbonate ion in groundwater with hydrogen ion as explained below;

$\mathrm{H}^{+}+\mathrm{CO}_{3}=\mathrm{HCO}_{3}^{-}$

Bicarbonate ion in groundwater could also be enriched through the biodegradation of organics in the presence of urea and nitrogenous wastes by de-nitrification (Akujieze and Oteze, 2007) as illustrated below;

$2 \mathrm{CH}_{2} \mathrm{O}+4 \mathrm{NO}_{3}=2 \mathrm{~N}_{2}(\mathrm{~g})+5 \mathrm{HCO}_{3}+\mathrm{H}++2 \mathrm{H}_{2} \mathrm{O}$

The $\mathrm{Ca}$ and $\mathrm{Mg}$ resulted from the leaching of plagioclase feldspars which are essential minerals in rocks (Adeyemi et al., 2003). Tijani (1994) reported that the $\mathrm{Ca}-(\mathrm{Mg})-\mathrm{HCO}_{3}$ type of chemical composition is due to the dissolution of silicate minerals in the bed rock and aluminosilicates in the weathered regolith. The
$\mathrm{Mg}^{2+} / \mathrm{Ca}^{2+}$ ratio vary from 0.3 to 2.4 with an average of 0.9 . According to $\mathrm{Hem}(1989)$ that $\mathrm{Mg}^{2+} / \mathrm{Ca}^{2+}$ ratios exceeding 0.9 indicate waters from silicate aquifers. Consequently, $39 \%$ of the samples revealed water from silicate aquifers 


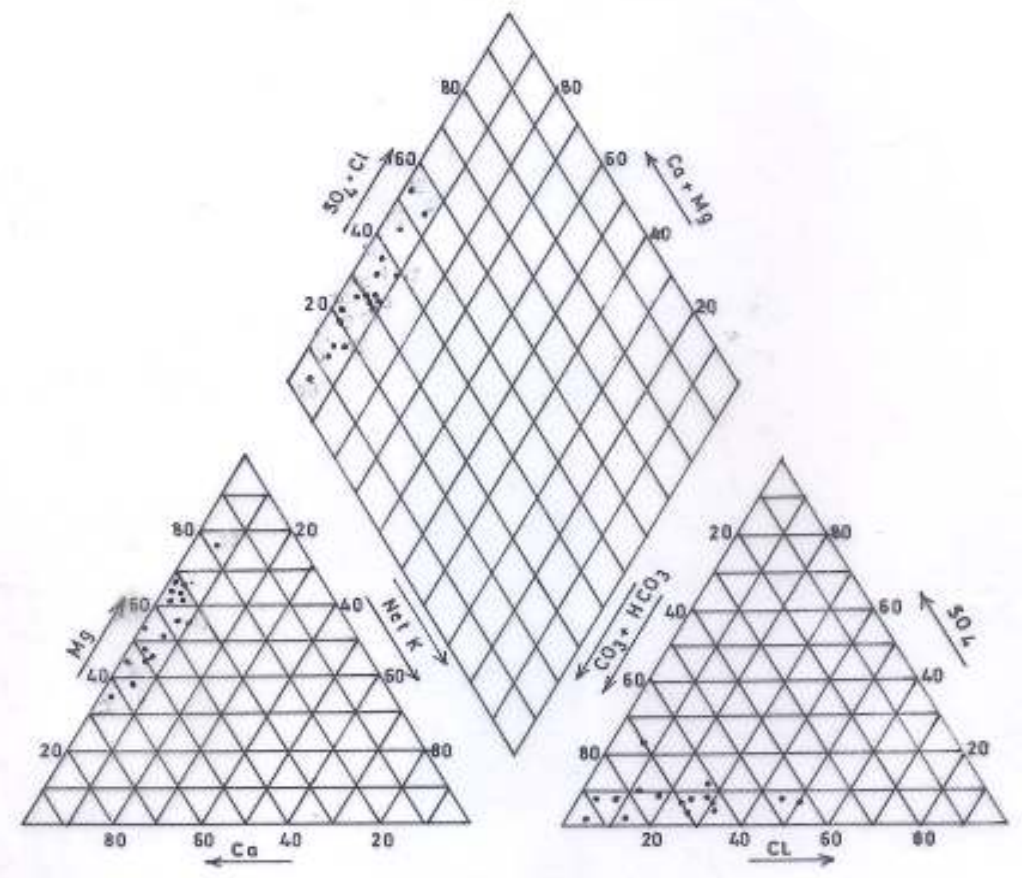

Fig. 4 Trilinear plots of some chemical data in the study area

From the plot of the logTDS values versus the ratios of $\mathrm{Na}^{+} /\left(\mathrm{Na}^{+}+\mathrm{Ca}^{2+}\right)$ (Table 4) on the Gibbs (1970) diagram (Fig.5), revealed that evaporation, weathering, and dilution could be responsible for the chemical behavior of the groundwater under different conditions. From Fig.5, the sample points cut across the evaporation, weathering, and dilution fields which are an indication that the chemistry of the groundwater in the area is a function of evaporation, weathering induced dissolution and dilution effects.

HYDROGEOCHEMICAL ASSESSMENT OF GROUNDWATER IN KA

Using a Peärson correlation analysis (Table 5) reveal a strong positive correlation between conductivity and TDS $(r=0.98), \mathrm{TH}$ and $\mathrm{Ca}(r=0.88), \mathrm{TH}$ and $\mathrm{Mg}$ $(r=0.78)$, TDS and $\mathrm{Ca}(r=0.76)$, TDS and TH $(r=0.63)$, $\mathrm{SO}_{4}$ and $\mathrm{Cu}(\mathrm{r}=0.54)$, and $\mathrm{NO}_{3}$ and $\mathrm{TH}(r=0.51)$. These 
strong positive correlations are indications that the chemical parameters have a common source. Positive correlation also exists between $\mathrm{Ec}$ and $\mathrm{pH}(\mathrm{r}=0.60)$, TDS and $\mathrm{pH}(\mathrm{r}=0.58)$, and $\mathrm{NO}_{3}$ and $\mathrm{pH}(\mathrm{r}=0.46)$. This positive correlation between $\mathrm{pH}$ and the chemical parameters is an indication that they have influence on each other. The strong positive correlation of TDS with other parameters is a clear indication that these parameters contributed to the overall TDS. The strong correlation between TDS and conductivity is an approximate relationship for most natural water (Richard, 1954). Total hardness reflects the contributions of calcium and magnesium. The strong positive correlations between $\mathrm{TH}$ and $\mathrm{Ca}$, and $\mathrm{TH}$ and $\mathrm{Mg}$ show that the total hardness of the water is caused primarily by $\mathrm{Ca}$ and $\mathrm{Mg}$ (Ariyo et al., 2005). The scatter plots of some positively correlated parameters are shown in Fig. 6. Negative correlation of some parameters such as $\mathrm{Fe}$ and $\mathrm{TH}(r=-0.62), \mathrm{Fe}$ and TDS $(r=-0.54)$, Fe and $\mathrm{Ca}(r=-0.50)$, Fe and $\mathrm{Mg}(r=-$ $0.50)$, and $\mathrm{Fe}$ and $\mathrm{Ec}(r=-0.48)$ (Table 6), suggest that these parameters are not from the same sources and could probably be explained that these parameters have no influence on each other. The scatter plots of some negatively correlated parameters are shown in Fig. 7. Regression analysis is a predictive model that predicts for the dependent variable whenever there is a change in independent variable. Regression model has the linear equation in the form of;

Table 4 Values of $\mathrm{Mg} / \mathrm{Ca}$ and $\mathrm{Na} /(\mathrm{Na}+\mathrm{Ca})$ ratios

\begin{tabular}{|c|c|c|c|c|}
\hline Sample Location & $\begin{array}{l}\text { Project } \\
\text { N0. }\end{array}$ & $\mathrm{Mg} / \mathrm{Ca}$ & $\mathrm{Na} /(\mathrm{Na}+\mathrm{Ca})$ & $\log T D S$ \\
\hline Kalarin & $\mathrm{BH} 1$ & 1.0 & 0.05 & 2.1 \\
\hline Kalorgu & $\mathrm{BH} 2$ & 0.3 & 0.05 & 2.2 \\
\hline Water cawans Sec. Sch. & $\mathrm{BH} 3$ & 1.1 & 0.05 & 2.3 \\
\hline General Hospital & $\mathrm{BH} 4$ & 0.8 & 0.10 & 2.4 \\
\hline Kulushin Clinic & $\mathrm{BH} 5$ & 0.7 & 0.08 & 2.2 \\
\hline Sch. of Health Tech. & $\mathrm{BH} 6$ & 0.7 & 0.08 & 2.4 \\
\hline NDP Sec. Okra & $\mathrm{BH} 7$ & 1.3 & 0.003 & 2.1 \\
\hline Cross Sabon Layi & $\mathrm{BH} 8$ & 0.4 & 0.08 & 2.5 \\
\hline Kasar Waje & HW1 & 0.5 & 0.02 & 2.5 \\
\hline Okra & HW2 & 2.4 & 0.20 & 1.9 \\
\hline Termana & HW3 & 1.0 & 0.03 & 2.3 \\
\hline Kulushin & HW4 & 0.8 & 0.04 & 2.2 \\
\hline Millinaire's Quarters A & HW5 & 0.6 & 0.05 & 2.6 \\
\hline Millinaire's Quarters B & HW6 & 1.2 & 0.04 & 2.4 \\
\hline Kaltungo Market & HW7 & 0.6 & 0.08 & 2.5 \\
\hline Old Palace & HW8 & 1.2 & 0.004 & 2.3 \\
\hline Obasanjo Stadium & HW9 & 0.9 & 0.1 & 2.3 \\
\hline Kwarin Kasar Waje & HW10 & 0.7 & 0.03 & 2.3 \\
\hline Average & & 0.9 & 0.06 & \\
\hline
\end{tabular}

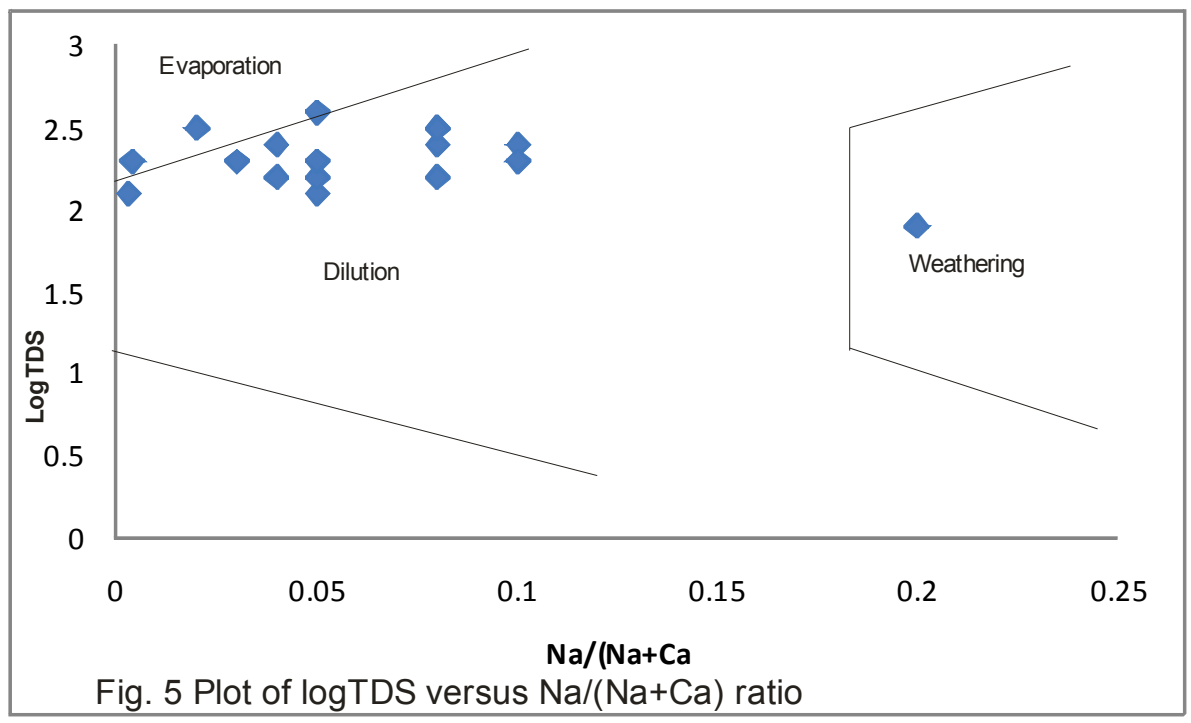


Table 5 Correlation between some hydrochemical parameters

\begin{tabular}{|l|l|}
\hline Variable & Correlation coefficient \\
\hline Conductivity and TDS & 0.98 \\
\hline TH and calcium & 0.88 \\
\hline TH and magnesium & 0.78 \\
\hline Conductivity and calcium & 0.78 \\
\hline TDS and calcium & 0.76 \\
\hline TDS and TH & 0.63 \\
\hline Ec and pH & 0.60 \\
\hline TDS and pH & 0.58 \\
\hline Sulphate and copper & 0.54 \\
\hline Nitrate and TH & 0.51 \\
\hline Nitrate and pH & 0.50 \\
\hline & \\
\hline
\end{tabular}




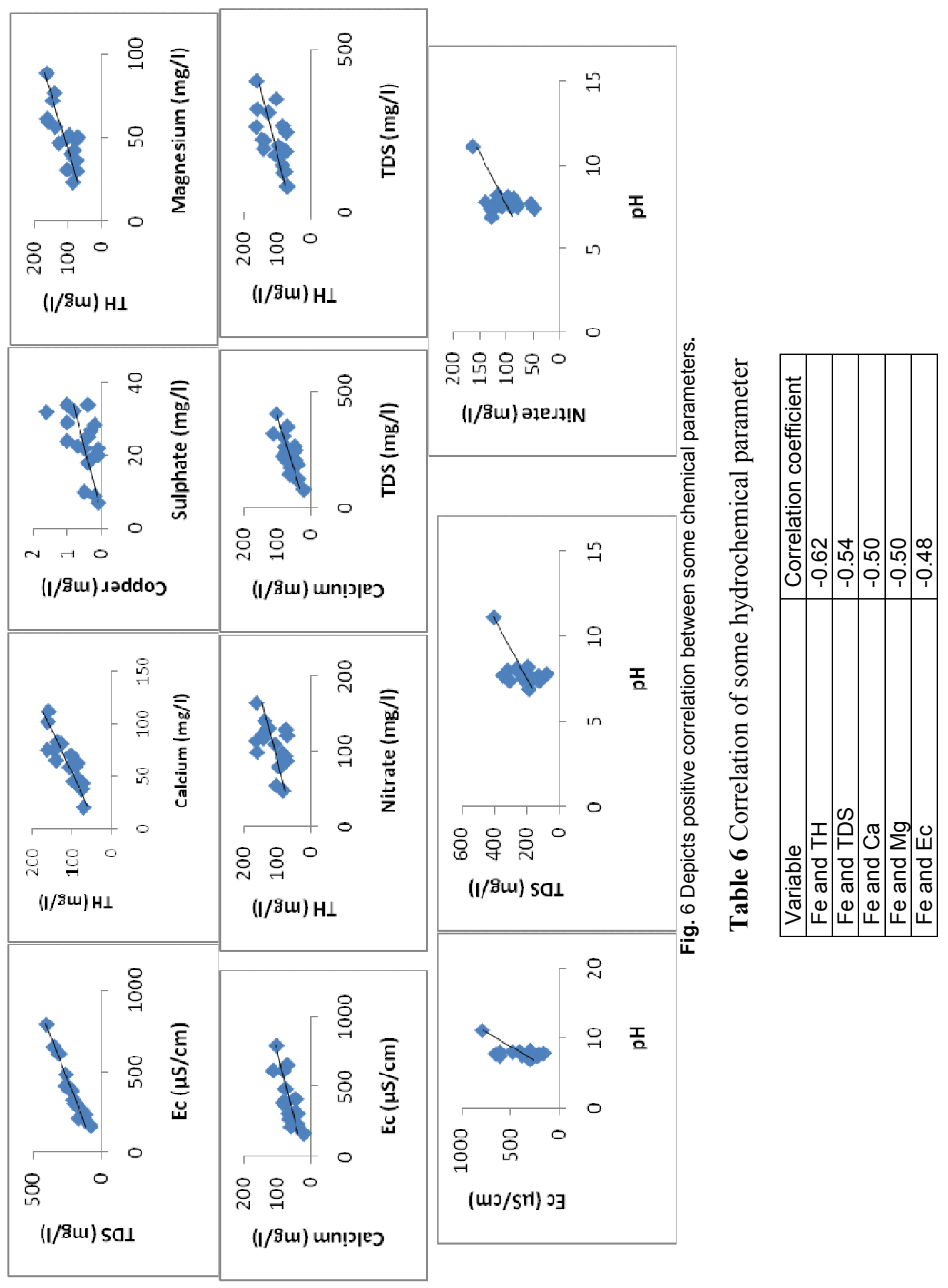




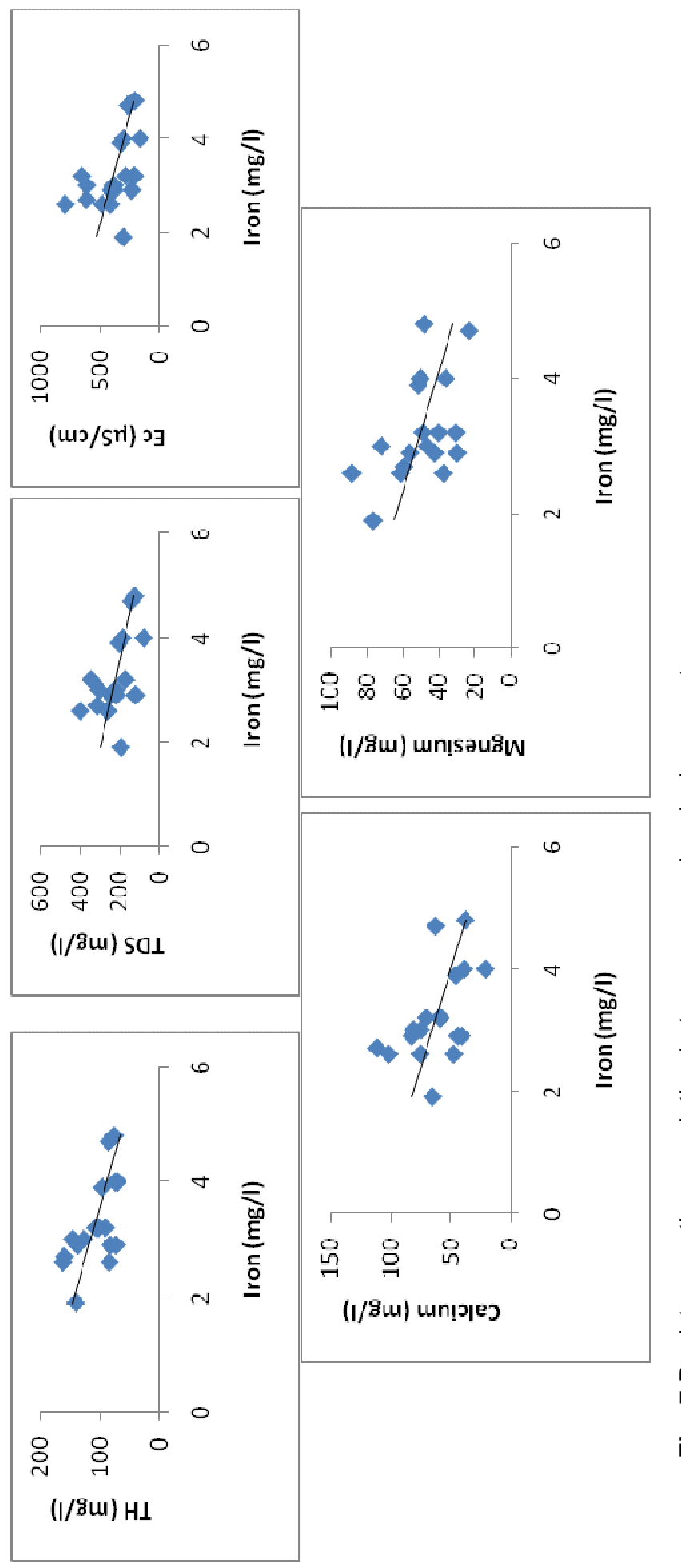

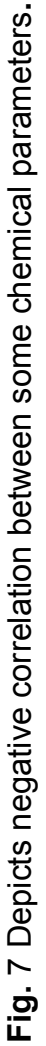


$\hat{Y}=a+b x$

The above equation is linear regression equation while the equation below is linear multiple regression equation.

$\hat{Y}=a+b_{1} x_{1}+b_{2} x_{2}+b_{3} x_{3}+b_{4} x_{4}$ $b_{n} x_{n}$ (Multiple regression).

Where,

$a=$ constant, $b=$ slope or rate of change of the independent variable $x$. based on the regression analysis, estimates of the linear and multiple regression equations developed for the study area are as follows;

TDS $=41.985+0.463 \mathrm{Ec}$.

$\mathrm{TH}=0.307+0.985 \mathrm{Ca}+\mathrm{Mg}$

TDS $=53.693+2.706 \mathrm{Ca}$

$\mathrm{SO}_{4}=17.438+10.833 \mathrm{Cu}$

$\mathrm{NO}_{3}=56.023+0.440 \mathrm{TH}$.

DS $-200.228-11.81 \mathrm{CO}_{3}+8.022 \mathrm{~K}+0.686 \mathrm{Ca}+7.241 \mathrm{Na}+0.294 \mathrm{NO}_{3}+0.139 \mathrm{HCO}_{3}+0.419 \mathrm{Cl}+6.817 \mathrm{SO}_{4}+$ 1.109Mg

For example in equation (12) the $\mathrm{x}_{1}=\mathrm{CO}_{3}, \mathrm{x}_{2}=\mathrm{K}, \mathrm{x}_{3}=\mathrm{Ca}, \mathrm{x}_{4}=\mathrm{Na}, \mathrm{x}_{5}=\mathrm{NO}_{3}, \mathrm{x}_{6}=\mathrm{HCO}_{3}, \mathrm{x}_{7}=\mathrm{Cl}, \mathrm{x}_{8}=\mathrm{SO}_{4}$ and $\mathrm{x}_{9}=\mathrm{Mg}$

Table 7 shows the results of the regression analysis between TDS and conductivity ( $R=0.95)$, TDS and $\mathrm{Ca}(\mathrm{R}=0.58)$, $\mathrm{SO}_{4}$ and $\mathrm{Cu}(\mathrm{R}=0.29)$, and $\mathrm{NO}_{3}$ and $\mathrm{TH}(\mathrm{R}=0.26)$. The $\mathrm{R}$ Square values used in the model explain how good a regression model is or how well data points fit in to the regression model. The results of $\mathrm{R}$ Square values suggest a common origin for the chemical parameters. The $\mathrm{R}$ Square between $\mathrm{SO}_{4}$ and $\mathrm{Cu}$, and $\mathrm{NO}_{3}{ }^{-}$and $\mathrm{TH}$ indicated weak relationships, but it also shows that the parameters could have resulted from a common source. Total hardness of the water in the area could be influenced by organic decomposition such as

Table 7 Regression analysis of some hydrochemical parameters

\begin{tabular}{|l|l|l|}
\hline \multicolumn{2}{|c|}{ Variable } & \multicolumn{1}{l}{} \\
\cline { 1 - 2 } Dependent & Independent & R Square \\
\hline TDS & Cond. & 0.95 \\
\hline TH & Ca and $\mathrm{Mg}$ & 0.99 \\
\hline TDS & $\mathrm{Ca}$ & 0.58 \\
\hline $\mathrm{SO}_{4}$ & $\mathrm{Cu}$ & 0.29 \\
\hline $\mathrm{NO}_{3}$ & $\mathrm{TH}$ & 0.26 \\
\hline TDS & $\mathrm{CO}_{3}, \mathrm{~K}, \mathrm{Ca}, \mathrm{Na}$, & 1.00 \\
& $\mathrm{NO}_{3}, \mathrm{HCO}$ \\
& $\mathrm{SO}_{4}, \mathrm{Mg}$, & \\
\hline
\end{tabular}

domestic effluent or sewage effluent. Multiple regression analysis between TDS and the major ions revealed R Square of 1.00 (Table 7). This relationship explains the contributions of the ions to the overall mineralization of the groundwater in the area. Multiple regressions between $\mathrm{TH}, \mathrm{Ca}$ and $\mathrm{Mg}$ revealed $\mathrm{R}$ Square of 0.99 which further confirms that the hardness of water is dependent on $\mathrm{Ca}$ and $\mathrm{Mg}$. Calcium may be released from feldspars, amphiboles, and pyroxenes, Mg may also be released from the above minerals or even clay minerals (Nton et al., 2007). TDS, TH, sulphate, and copper could be influenced by waste disposal practices. Fig. 8 shows the linear regression curves of some chemical parameters. The correlation and regression analyses revealed that the dissolved geochemical constituents in groundwater in the area could have been derived from similar sources. 

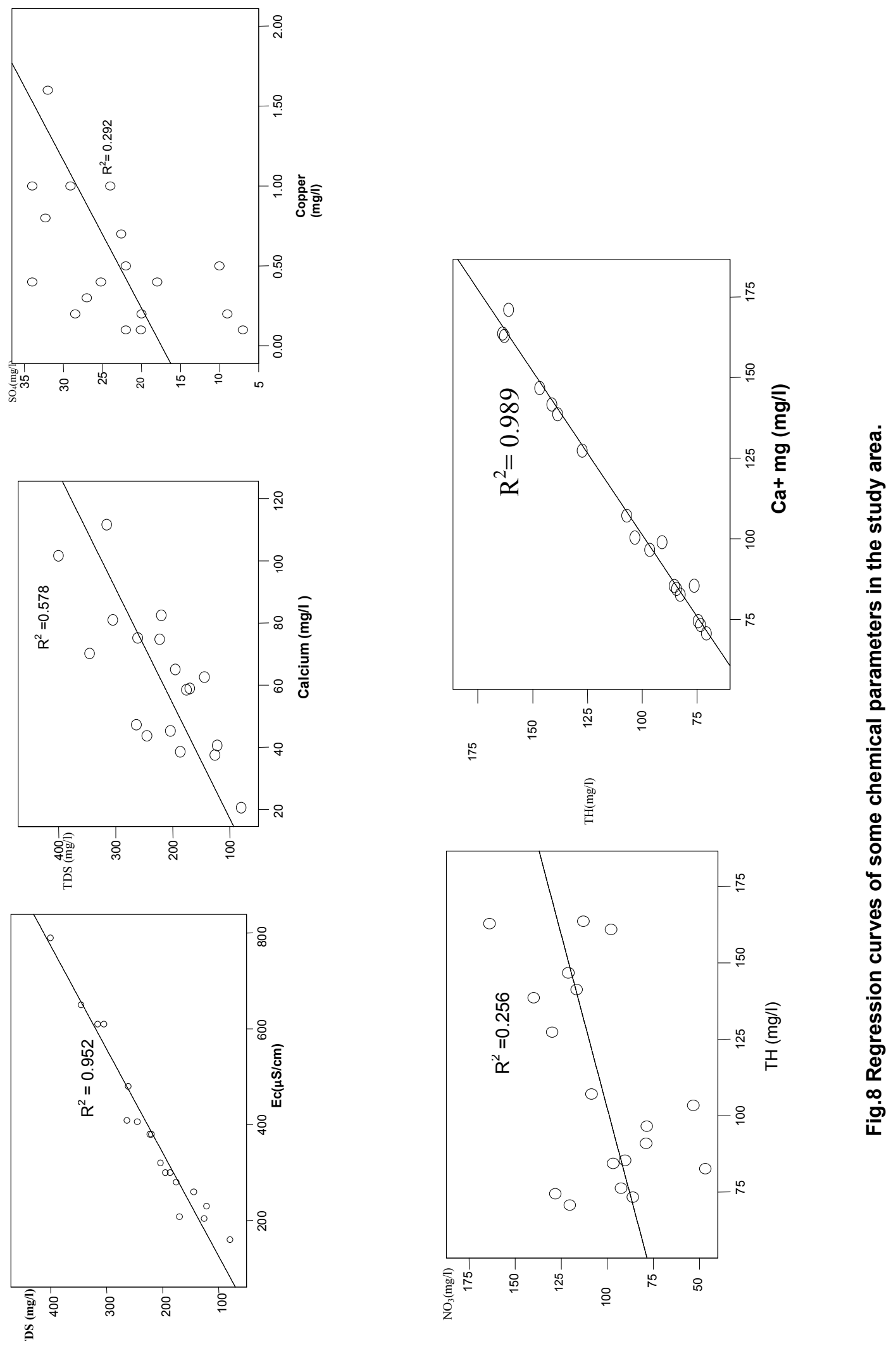


\section{CONCLUSIONS}

The following conclusions can be drawn from this study:

1. The study area is underlain by the basement complex rocks which consist of the porphyritic and biotite granites. The porphyritic granites are coarse to very coarse grained in texture with large white or pinkish prismatic phenocrysts of microcline. The biotite granites have granular texture with wide range of textures.

2. Borehole lithologic logs revealed fractured aquifer system which range from $12 \mathrm{~m}$ to $24 \mathrm{~m}$ in thickness. Borehole yields range from $3.31 / \mathrm{s}$ to $16.71 / \mathrm{s}$.

3. The results of 18 water samples collected from the hand-dug wells and boreholes revealed that the groundwater is polluted due to high concentrations of iron, fluoride, nitrate, and coliform bacteria. The results further revealed that the water is generally good for agricultural practices but may not be suitable for some industries.

4. Plots of chemical data on trilinear diagram revealed that the water in the area is of $\mathrm{Ca}$ (mg)- $\mathrm{HCO}_{3}$ which belongs to the normal alkaline fresh water type.

5. Based on $\mathrm{Mg}^{2+} / \mathrm{Ca}^{2+}$ ratio, about $39 \%$ of the water samples reveal water from the silicate aquifer. The plot of logTDS against $\mathrm{Na}^{+} /\left(\mathrm{Na}^{+}\right.$ $+\mathrm{Ca}^{2+}$ ) ratio indicated that the groundwater chemistry in the area is controlled by evaporation, weathering induced dissolution and dilution effects.

6. Correlation and regression analyses on chemical data revealed that the parameters could be from similar source.

7. Groundwater quality in the area is controlled by the geology and anthropogenic activities.

8. The water quality is unfit for human consumption due to bacteriological pollution, and high concentrations of iron, fluoride, and nitrate. The water would require treatment to be used for domestic and industrial purposes in the area.

9. High groundwater velocities in fractures and thin overburden materials could be responsible for the wide range of groundwater quality deterioration in the area. It is recommended that regular water quality monitoring will ensure groundwater quality protection and conservation.

\section{REFERENCES}

Abimbola, A.F., T.A., Okunola, O.W., Odewande, A.A., Ajibade, O.M. and Kolawale, T. 2005. Water quality test of areas surrounding selected refuse dumpsites in Ibadan, Southwestern Nigeria. Water Resources- Journal of the Nigerian Association of Hydrogeologists (NAH) 16: 39-48.
Adeyemi, G.O., Adesile, A.O. and Obayomi, O.B. 2003. Chemical characteristics of some well waters in Ikire Southwestern Nigeria. Water ResourcesJournal of the Nigerian Association of Hydrogeologists (NAH), vol. 14, pp 12-18.

Alao, D.A. and Ige, O.O. 2003. Preliminary Assessment of pollution of Asa River using physic-chemical indices. Water Resources- Journal of the Nigerian Association of Hydrogeologists (NAH), vol. 14, pp 25-30.

Akujieze, C.N. and Oteze, G.E. 2007. Deteriorating quality of groundwater in Benin city, Edo State Nigeria. Water Resources- Journal of the Nigerian Association of Hydrogeologists (NAH), vol. 17, pp 17-23.

Amadi, U.M.P. 1987. Mixing phenomenon in groundwater systems and its relevance in water quality assessment in Nigeria. In: K. Iwugo (ed) paper presented at the $2^{\text {nd }}$ annual symposium conference of the Nigerian Water and Sanitation Association, pp 17:1-17:31.

Ariyo, S.O., Adeyemi, G.O. and Odukoya, A.M. 2005. Geochemical characterization of aquifers in the basement complex-sedimentary transition zone around Ishara, Southwestern Nigeria. Water Resources- Journal of the Nigerian Association of Hydrogeologists (NAH), vol. 16, pp31-38.

Barcelona, M.J., Gibb, J.P., Helfrich, J.A. and Garske, E.E. 1985. Practical guide for groundwater sampling. ISWS contract report 374. Illinois State Water Survey Campaign, Illinois, 94p.

Bassey, N.E. 2006. A tectonic interpretation of a linear magnetic anomaly over Chibok, N.E Nigeria. Global Journal of Geological Sciences vol. 4, N0. 1, pp73-78

Benkhelil, M.J. 1982. Strctural map of the Upper Benue Valley. Journal of Mining and Geology 18, pp140-151.

Bowman, J. 1994. 'Water is best': Would Pindar still think so? In: Cartledge B (ed) Health and the environment. The Linacre lectures 1992-3. Oxford University Press, Oxford, pp 85-125.

California Fertilizer Committee, 1975. Western Fertilizer Hand-book. The Interstate Printers and Publishers. Inc. Danville, Illinois.

Canter, L.W. 1996. Nitrates in groundwater. Lewis Publ. New York, 263p.

Carter, J.D., Barber, W. and Tait, E.A. 1963. The geology of parts of Adamawa, Bauchi and Bornu provinces in Northeastern Nigeria. Bull. 30, Geological Survey of Nigeria. 243p. 
Chilton, J. 1992. Groundwater. Water quality Assessment- A guide to use of Biota; sediments and water in environmental monitoring. $2^{\text {nd }}$ ed. UNESCO/WHO/UNEP.

Gibbs, R.J. 1970. Mechanism controlling world water chemistry. Science 170, pp 1088-1090.

Gombe State Rural Water Supply and Environmental Sanitation Agency. 2003. Unpublished borehole data report.

Hem, J.D. 1970. Study and Interpretation of the chemical characteristics of natural waters. US. Geological Survey. Water Supply Paper, 1473, Reston, VA 363p D.C, 263p.

Hem, J.D. 1989. Study and Interpretation of the chemical characteristics of natural waters. US. Geological Survey Water Supply Paper, 2254 $\left(3^{\text {rd }}\right.$ ed $), 263 p$

Levison, J. and Novakowski, K. 2009. The impact of cattle pasturing on groundwater quality in bed rock aquifers having minimal overbudden. Hydrogeology Journal 17: 559-569.

Mandel, S. and Shiftan, Z.I. 1981. Groundwater Res. Investigation and development. Academic press. Inc.

National Population Commission (NPC). 2006. Population of the Federal Republic of Nigeria. Gombe State Statistical Table. National Population Commission final results of population census of Nigeria.

Nigerian Geological Survey Agency. 2006. Geological Map of Nigeria. Published by Federal Government of Nigeria.

Nton, M. E. Adejumo, S.A. and Elueze, A.A. 2007. Hydrogeochemical Assessment of surface water and groundwater quality in Agbowo-Orogun area of Ibadan, Southwestern Nigeria. Global Journal of Geological Sciences, vol. 1\&2, pp 1323.

Ntekim, E.E. and Orazulike, D.M. 2004. Structural and lithological characteristics of Lamurde-Lau area in Upper Benue Trough, N.E, Nigeria: A strategy for gypsum prospecting. Nig. J. Pure \& Appl. Sci. Vol.19, pp1692-1697

Piper, A.M. 1944. A graphical procedure in geochemical interpretation of water analysis. Trans. America Geophysical Union 25: 914-923.

Rahman, M.A. 1976. Recent Advances in the study of basement complex of Nigeria. Pre. Geol. Nig. Publication. GSN, pp 11-13.

Richards, L.A. 1954. Diagnosis and improvement of saline and alkali soils. Agric. Handbook 60. US. Dept. Agric. Washington, D.C. 160p.

Sawyer, C.N. and McCarty, P.I. 1967. Chemistry for Sanitary engineers. $2^{\text {nd }}$ edition, McGraw-Hill, New York.

Siddiqi, M., Kumar, R., Fazali, Z., Spiegelhalder, B., and Preussmann, R. 1992. Increased exposure to dietary amines and nitrate in a population and high risk of oesophageal and gastric cancer in Kashmir (India): Carcinogenesis, vol. 13, pp 1331-1333.

Tijani, M. N. 1994. Hydrogeochemical Assessment of groundwater in Moro area, Kwara State, Nigeria. Environ. Geol. 24, pp 194-202.

Todd, D.K. 1980. Groundwater Hydrology. $2^{\text {nd }}$ (ed) J. Wiley and Sons. New York 535p.

Van Breeman, o., Pidgeon, R.T. and Bowden, p. 1977. Age and Isotopic studies of some Pan African granites from central Nigeria, precamb. Res., vol. 4, pp 307-319.

WHO (World Health organization), 1984. Guidelines for drinking water quality, vol. 1. Recommendations. World Health Organization. Geneva. 130p.

WHO (World Health Organization), 1985. Guidelines for drinking water quality vol.3 World Health organization, Geneva, 121p.

WHO (World Health organization), 1993. Guidelines for drinking water quality. Vol. 2. Recommendations. Geneva. Switzerland. 